\title{
DAMPAK BEA KELUAR KAKAO INDONESIA TERHADAP COUNTRY MARKET POWER DI PASAR BIJI KAKAO AMERIKA SERIKAT DAN TERMS OF TRADE
}

\author{
Ari Harsanti ${ }^{1}$, Bambang Juanda ${ }^{2}$ dan Sahara ${ }^{2}$ \\ 1)Staf pada Kementerian Perdagangan RI dan Mahasiswa Program Studi Ilmu Ekonomi, \\ Departemen Ilmu Ekonomi, Fakultas Ekonomi dan Manajemen IPB \\ 2)Departemen Ilmu Ekonomi, Fakultas Ekonomi dan Manajemen, Institut Pertanian Bogor \\ e-mail : 1) ariharsanti@yahoo.com
}

\begin{abstract}
As the world's third-largest cocoa beans producer, Indonesia is expected to have a comparative advantage and to become cocoa beans price reference. This research investigates market power of Indonesia cocoa beans export for the United State market as an impact of an export tax. Five cocoa beans exporting countries namely Cote d'Ivoire, Ecuador, Ghana, Dominica Rep and Nigeria are calculated their market power as Indonesia's competitors by estimating residual demand elasticity with two stage least square method. The results show that Indonesia's market power suffered after imposing the export tax. Cote d'Ivoire and Ghana get advantages from this export restriction. The effect of export tax on welfare is analyzed by calculating terms of trade. The gain from cocoa beans trade depicts a declining terms of trade for dealing with the international cocoa beans market.
\end{abstract}

Keywords: market power, residual demand elasticity, cocoa beans, Indonesia, terms of trade, two stage least square

\section{PENDAHULUAN}

Kakao adalah salah satu komoditas pertanian yang hanya dihasilkan di negaranegara beriklim tropis. Dalam pasar internasional, negara produsen kakao jumlahnya sangat terbatas. Menurut International Cocoa Organization (ICCO) pada tahun 2011/2012 berdasarkan wilayah dan pangsa produksi kakao adalah sebagai berikut: Afrika (71,5 persen): Pantai Gading, Ghana, Nigeria dan Kamerun; Asia/Oceania (12,5 persen): Indonesia, Malaysia, Papua Nugini; dan Amerika (16 persen) : Brazil, Ekuador dan Kolombia.

Gambar 1 menunjukkan produksi kakao dunia dari enam negara penghasil utama. Produksi biji kakao dunia pada tahun 2011/2012 mencapai 4.095.000 ton dimana penghasil kakao terbesar dunia adalah Pantai Gading dengan produksi sebesar 1.486 .000 ton, selanjutnya Ghana memproduksi 879.000 ton, Nigeria sebesar 245.000 ton dan Kamerun 207.000 ton. Indonesia menghasilkan biji kakao 440.000 ton. Sementara Brazil mem- produksi 220.000 ton dan Ekuador sebesar 198.000 ton. Produksi kakao Pantai Gading selama tahun 2003 hingga 2010 mengalami fluktuasi volume yang diakibatkan cuaca buruk. Nilainya berkisar dari 1.223.153 ton hingga 1.407.213 ton.

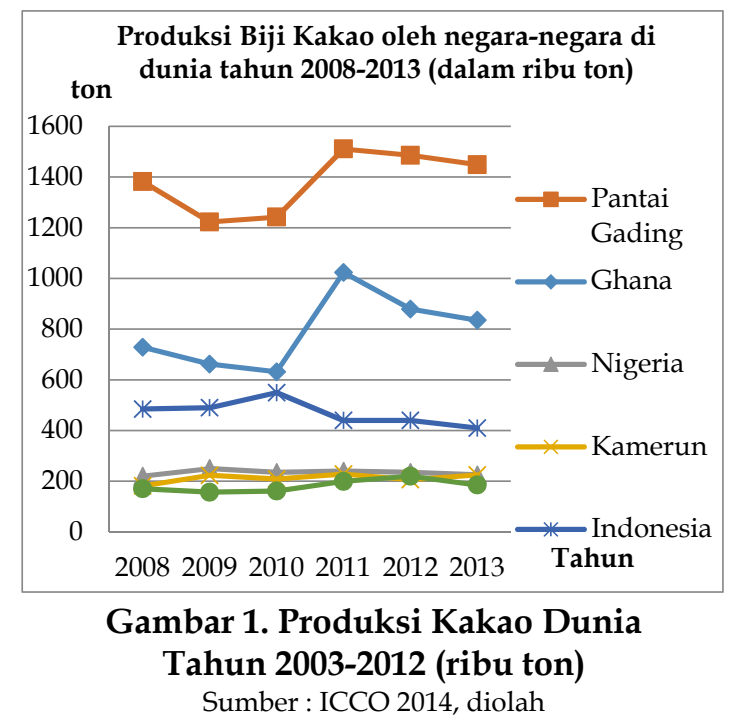

Namun setelah tahun 2010, negara tersebut berhasil meningkatkan produksinya sebesar 258.094 ton dari tahun sebelumnya. 
Agritrade Special Report tahun 2012 menyebutkan bahwa keberhasilan Pantai Gading sebagai produsen kakao dunia ditunjang oleh liberalisasi perdagangan kakao dan bantuan dari Bank Dunia. Sementara itu produksi kakao di Indonesia juga mengalami fluktuasi volume dari tahun 2003 hingga tahun 2010 dengan rata-rata produksi $762.885,8$ ton per tahun. Kemudian produksi kakao Indonesia pada tahun 2011 turun sebesar 132.426 ton dari tahun 2010. Penurunan produksi ini diakibatkan oleh perubahan iklim yang ekstrem, hama penyakit dan umur tanaman yang sudah tua (Nurhayat 2014). Pada tahun 2003, Ghana memproduksi kakao sebesar 497.000 ton. Selanjutnya pada tahun 2004 hingga 2011, produksi kakao Ghana meningkat dengan rata-rata 693.622 ton per tahun.

Selama enam tahun, ekspor biji kakao didominasi oleh Pantai Gading dan negara Afrika lainnya, Indonesia juga merupakan eksportir biji kakao terbesar ke dunia. Gambaran ekspor biji kakao dari negara eksportir utama tercakup dalam Tabel 1. Ekspor biji kakao Indonesia sebesar 74 persen dari total produksi biji kakao sisanya diserap oleh industri pengolahan kakao domestik di tahun 2012. Biji kakao diolah menjadi cocoa butter, cocoa powder, cocoa cake, dan cocoa liquor. Menurut laporan ICCO tahun 2012, konsumsi kakao domestik Indonesia meningkat dari tahun 11.000 ton menjadi 22.900 ton di tahun 2011. Selain sebagai negara penghasil kakao, Indonesia juga mengekspor komoditi kakao ke seluruh dunia.

Trend ekspor kakao dan produk kakao menunjukkan peningkatan dari tahun 2008 hingga 2013. Menurut TradeMap (2014) ekspor biji kakao menyumbang 446.095 ribu US\$, ekspor cocoa butter sebesar 356.764 ribu US\$ dan cocoa paste sebesar 110.445 ribu US\$ terhadap Pendapatan Domestik Bruto Indonesia di tahun 2013.

Tabel 2 memperlihatkan perkembangan nilai ekspor biji kakao Indonesia ke pasar internasional dari tahun 2009 hingga 2013. Negara tujuan ekspor utama biji kakao Indonesia adalah Malaysia dan Amerika Serikat. Singapura, China, India dan Thailand adalah importir biji kakao Indonesia. Selain itu Jerman dan Belanda, juga merupakan negara tujuan ekspor biji kakao Indonesia. Pangsa ekspor terbesar adalah ke pasar Malaysia yaitu sebesar 67,7 persen dari total ekspor biji kakao di tahun 2013. Tren ekspor ke Malaysia turun sebesar 15,6 dengan pertumbuhan di tahun 2012/2013 sebesar 33,8 persen.

Amerika Serikat adalah pembeli biji kakao terbesar di dunia setelah Uni Eropa. Pasar Amerika Serikat merupakan tujuan utama ekspor biji kakao dan produk kakao Indonesia. Sejak tahun 1967 telah tercatat perdagangan biji kakao antara Indonesia dan Amerika Serikat. Hanya pasar Amerika Serikat dan juga Malaysia yang masih menerima biji kakao Indonesia yang belum difermentasi. Amerika Serikat sangat membutuhkan biji kakao dari Indonesia karena kandungan lemaknya sebagai campuran dalam industri pengolahan kakao sedangkan Uni Eropa lebih mensyaratkan biji kakao yang sudah difermentasi karena menghendaki flavor dan kandungan lemak dari biji kakao. Ekspor biji kakao Indonesia terbesar adalah ke Malaysia padahal negara tersebut juga merupakan penghasil biji kakao dan juga eksportir biji kakao. Hal ini tidak mengherankan karena perusahaan pengolah cokelat terbesar di Indonesia, Ceres Grup melakukan ekspansi di Asia Tenggara, akibatnya per-mintaan biji kakao dari Malaysia melonjak tajam (Panlibuton dan Meyer 2004). Bibit tanaman kakao Indonesia sendiri juga awalnya berasal dari Malaysia. Sementara itu pasar biji kakao Amerika Serikat merupakan tujuan ekspor dari negaranegara penghasil biji kakao terbesar di dunia. Indonesia di pasar Amerika Serikat bersaing dengan negara-negara produsen biji kakao terbesar lainnya seperti Pantai Gading, Ghana, Ekuador, Nigeria, dan Republik Dominika. Pangsa ekspor biji kakao terbesar masih diduduki oleh Pantai Gading. Oleh karena itu menganalisis kinerja ekspor biji kakao di pasar Amerika Serikat dapat digunakan untuk menunjukkan bagaimana daya saing biji kakao Indonesia di dunia. 
Tabel 1. Perkembangan Ekspor Biji Kakao dari Tujuh Negara Eksportir Terbesar Dunia 2008-2013 (ton)

\begin{tabular}{|l|r|r|r|r|r|r|}
\hline $\begin{array}{l}\text { Negara eksportir } \\
\text { biji kakao }\end{array}$ & \multicolumn{10}{|c|}{ Volume ekspor (ton) } \\
\hline Pantai Gading & $\mathbf{2 0 0 8}$ & $\mathbf{2 0 0 9}$ & $\mathbf{2 0 1 0}$ & \multicolumn{1}{|c|}{$\mathbf{2 0 1 1}$} & \multicolumn{1}{c|}{$\mathbf{2 0 1 2}$} & \multicolumn{1}{c|}{$\mathbf{2 0 1 3}$} \\
\hline Ghana & 782.868 & 917.700 & 790.912 & 1.073 .282 & 1.011 .631 & 1.166 .001 \\
\hline Belanda & 474.706 & 395.711 & 281.437 & 629.081 & 585.929 & 676.724 \\
\hline Nigeria & 27.773 & 167.521 & 167.081 & 207.773 & 181.726 & 214.516 \\
\hline Indonesia & 380.513 & 439.305 & 432.427 & 210.067 & 163.501 & 188.420 \\
\hline Kamerun & 178.101 & 193.973 & 193.881 & 190.214 & 173.794 & 181.277 \\
\hline Ekuador & 86.372 & 126.969 & 116.318 & 157.782 & 147.329 & 178.273 \\
\hline Total dunia & 2.635 .632 & 2.939 .485 & 6.071 .839 & 4.957 .028 & 3.883 .484 & 3.287 .177 \\
\hline
\end{tabular}

Sumber: UN Comtrade 2014

Tabel 2. Negara Tujuan Utama dari Ekspor Biji Kakao Indonesia 2009-2013 (seribu US\$)

\begin{tabular}{|c|c|c|c|c|c|c|c|c|}
\hline \multirow{2}{*}{ Negara } & \multicolumn{5}{|c|}{ Nilai ekspor (seribu dollar Amerika Serikat) } & \multirow{2}{*}{$\begin{array}{c}\text { Tren } \\
\text { 2009-2013 }\end{array}$} & \multirow{2}{*}{$\begin{array}{c}\text { Pertumbuhan } \\
\text { 2012-2013 }\end{array}$} & \multirow{2}{*}{$\begin{array}{c}\text { Pangsa } 2013 \\
(\%)\end{array}$} \\
\hline & 2009 & 2010 & 2011 & 2012 & 2013 & & & \\
\hline Malaysia & 451.583 & 550.917 & 411.106 & 225.748 & 302.162 & $-15,6 \%$ & $33,8 \%$ & $67,7 \%$ \\
\hline Singapura & 139.239 & 151.484 & 9.8421 & 92.791 & 72.680 & $-16,4 \%$ & $-21,7 \%$ & $16,3 \%$ \\
\hline Thailand & 17.846 & 18.477 & 17.207 & 18.719 & 19.405 & $1,8 \%$ & $3,7 \%$ & $4,3 \%$ \\
\hline China & 17.007 & 42.741 & 22.940 & 13.551 & 19.200 & $-8,7 \%$ & $41,7 \%$ & $4,3 \%$ \\
\hline Amerika Serikat & 297.013 & 246.501 & 29.671 & 628 & 16.439 & $-69,2 \%$ & $2.517 .7 \%$ & $3,7 \%$ \\
\hline India & 4.542 & 10.752 & 14.032 & 11.768 & 13.625 & $25,7 \%$ & $15,8 \%$ & $3,1 \%$ \\
\hline Jerman & 20.715 & 35.167 & 1.048 & 1.098 & 722 & $-63,9 \%$ & $-34,2 \%$ & $0,2 \%$ \\
\hline Belanda & 5.816 & 15.564 & 2.758 & 1.917 & 562 & $-49,2 \%$ & $-70,7 \%$ & $0,1 \%$ \\
\hline Total dunia & 1.087 .485 & 1.190 .740 & 614.496 & 384.830 & 446095 & $-25,3 \%$ & $15,9 \%$ & $100,0 \%$ \\
\hline
\end{tabular}

Sumber: UN Comtrade 2014 (diolah)

Keunggulan komparatif dalam ekspor biji kakao seharusnya menjadi potensi bagi Indonesia untuk mempunyai kekuatan dalam menentukan harga kakao dunia (Firdaus, M dan Ariyoso 2010). Pasokan kakao yang sering defisit menjadi peluang bagi kakao Indonesia. Daya saing kakao Indonesia di pasar Amerika Serikat menjadi fokus dalam penelitian ini. Persaingan dengan negara lain terutama dalam mendapatkan harga kakao yang tinggi di pasar Amerika Serikat merupakan hal penting dalam menilai suatu kinerja ekspor. Kemampuan untuk mengendalikan harga dikenal sebagai market power mencerminkan selisih antara harga dan biaya marjinal dalam suatu industri. Isu market power dalam sektor pertanian semakin meningkat karena perusahaan-perusahaan terkonsolidasi melalui rantai pemasaran (Sexton dan Zhang 2001).

Di sisi lain ekspor biji kakao yang belum diolah merupakan hal yang tidak menguntungkan bagi Indonesia karena tidak terdapat nilai tambah. Pada bulan April 2010, pemerintah mengeluarkan kebijakan Peraturan Menteri Keuangan No.67/PMK.011/ 2010 tentang Bea dan Tarif Keluar Biji kakao. Pengenaan pajak ekspor bagi kakao yang belum diolah ini bertujuan untuk mendukung tersedianya pasokan biji kakao bagi industri pengolahan kakao domestik. Akibat dari kebijakan tersebut nilai ekspor kakao menurun tajam dari 1.190.740 ribu dolar Amerika pada tahun 2010 menjadi 614.496 ribu dolar Amerika Serikat. Tren ekspor dari tahun 2009 hingga 2013 menunjukkan penurunan sebesar 25,3 persen.

Bea keluar biji kakao merupakan salah satu bentuk intervensi pemerintah dalam pasar pertanian internasional. Dampak dari pengenaan bea keluar terhadap ekonomi suatu negara tergantung pada market power yang dimiliki oleh negara tersebut (Piemartini 2004). Negara-negara dengan market power yang mengenakan peraturan pajak ekspor lebih mempunyai pengaruh terhadap harga internasional, volume perdagangan, distri- 
busi pendapatan, dan terms of trade daripada negara tanpa market power. Sementara, dampak negatif yang lebih signifikan pada pertumbuhan ekonomi dan kesejahteraan nasional akan dialami oleh negara tanpa market power (Devarajan et al. 1996). Sebuah negara dengan market power menerapkan suatu pajak ekspor, akan mengalami kehilangan efisiensi karena dampak distorsi dari pajak ekspor, namun terms of trade akan membaik, yaitu harga relatif ekspor negara tersebut dibandingkan dengan impornya.

Justifikasi dari dasar pemikiran pengenaan bea keluar selain untuk memberikan subsidi tidak langsung terhadap industri hilir, juga dianalisis untuk memperbaiki terms of trade. Dengan membatasi ekspornya, suatu negara dengan pangsa ekspor komoditi di dunia cukup besar dapat menaikkan harga komoditinya sehingga akan meningkatkan terms of trade negara tersebut (Bouet dan Debucquet 2010). Terms of trade merupakan suatu ukuran untuk menganalisis kesejahteraan nasional sebagai hasil dari perdagangan internasional. Terms of trade suatu negara didefinisikan sebagai harga ekspor dibagi dengan harga impor negara tersebut. Suatu peningkatan terms of trade akan meningkatkan kesejahteraan nasional dan suatu penurunan terms of trade akan menurunkan kesejahteraan nasional. Berkaitan dengan tarif ekspor maupun impor muncul adanya argumen Terms of Trade untuk tarif dimana menurut Krugman (2012) berasal dari analisis biaya dan keuntungan. Bagi negara importir besar yang mampu mempengaruhi harga dari negara eksportir, suatu tarif impor akan menurunkan harga impor dan menghasilkan keuntungan terms of trade. Keuntungan ini harus diatur terhadap biaya tarif, dimana biaya akan meningkat karena tarif akan mengurangi insentif produksi dan konsumsi. Namun adakalanya dalam beberapa kasus keuntungan dari terms of trade lebih banyak daripada biayanya, hal ini disebut sebagai argumen terms of trade untuk tarif.

Berdasarkan latar belakang dan perumusan masalah yang telah diuraikan maka tujuan yang ingin dicapai dalam penelitian ini adalah sebagai berikut:

1. Menganalisis market power ekspor biji kakao Indonesia di pasar Amerika setelah dikenakan pajak ekspor.

2. Menganalisis market power negara pesaing terhadap ekspor biji kakao di pasar Amerika dengan adanya pajak ekspor.

3. Menganalisis terms of trade dari ekspor biji kakao Indonesia selama kurun waktu 2000-2013.

\section{TINJAUAN TEORITIS}

Dampak pengenaan pajak ekspor pada komoditi tertentu telah banyak dianalisis. Rifin (2012) mengelompokkan hasil-hasil penelitian tersebut menjadi dua kelompok. Kelompok yang pertama adalah penelitian yang bertujuan menghitung besarnya pajak optimum dan menganalisa dampak pajak ekspor terhadap kesejahteraan. Sedangkan kelompok yang kedua hanya menganalisa dampak dari kebijakan pajak ekspor terhadap kesejahteraan dan ekonomi. Seluruh penelitian tersebut mempunyai dampak negatif terhadap ekonomi dan mengurangi daya saing komoditi yang dikenakan pajak ekspor. Sementara itu dampak dari pengenaan bea keluar terhadap ekonomi suatu negara tergantung pada market power yang dimiliki oleh negara tersebut (Piemartini 2004). Negara-negara dengan market power yang mengenakan peraturan pajak ekspor lebih mempunyai pengaruh terhadap harga internasional, volume perdagangan, distribusi pendapatan, dan terms of trade daripada negara tanpa market power.

Nwachukwu et al (2011) menganalisa derajat market power ekspor komoditi kakao negara Nigeria dalam pasar Belanda menggunakan pendekatan New Empirical Industrial Organization (NEIO). Daya saing ekspor kakao Nigeria ditunjukkan dengan indeks market power dan indeks Lerner yang diperoleh dari estimasi model simultan menggunakan metode 2SLS. Penelitian ini menggunakan data consumer price index (CPI) yang sesuai dengan Susanto (2006). Negara utama yang 
berpartisipasi dalam pasar Belanda adalah Kamerun, Pantai Gading, Ghana, Indonesia dan Malaysia berdasarkan suplai negara tersebut yang diatas 1000 ton per tahun ke dalam pasar. Koefisien indeks market power untuk Nigeria diestimasi sebesar $-0,712$ dan indeks Lerner sebesar 0,122 sehingga disimpulkan ekspor kakao Nigeria mempunyai competitiveness di pasar Belanda.

Susanto (2006) dalam disertasinya mengukur derajat oligopoly power dalam permintaan ekspor soybean complex menggunakan pendekatan NEIO untuk memodelkan monopoly, kompetisi dan oligopoly. Metode ekonometrika yang digunakan adalah error correction model (ECM). Uji hipotesis market power dilakukan dengan estimasi hubungan demand dan supply. Sebelumnya Deodhar dan Sheldon (1997) mengestimasi persaingan tidak sempurna dalam pasar dunia untuk ekspor soymeal dengan model ekonometrika non-linier three-stage least square.

Pengukuran market power juga berhubungan dengan kebijakan persaingan untuk melindungi kepentingan konsumen dan meningkatkan efisiensi pasar seperti pada penelitian yang dilakukan Deodhar dan Pandey (2006). Derajat kompetisi berhubungan dengan derajat transmisi harga antara petani dan konsumen akhir juga tergantung kepada derajat sektor pemrosesan. Mereka menganalis derajat kompetisi di pasar kopi instant dengan mengukur parameter conjectural $(\lambda)$ sebagai parameter market power secara ekonometrika menggunakan metode 3SLS. Hasil estimasi menunjukkan $\lambda=0,123$ lebih dekat ke 0, menunjukkan industri kopi instant tidak mempraktekkan kolusi. Durevall (2005) telah menganalisa peranan harga dalam menentukan permintaan kopi sangrai di Swedia. Determinan utama dari permintaan adalah perbedaan dalam selera lintas generasi dalam kombinasi dengan dinamika populasi, konsumen yang lahir sebelum tahun 1960an meminum lebih banyak kopi daripada generasi yang lebih muda. Penurunan harga kopi hanya mempunyai efek short-run pada konsumsi. Derajat persaingan yang tinggi dalam pasar kopi sangrai Swedia karena evolusi konsumsi long-run tidak tergantung pada harga. Penelitian lainnya yang dilakukan oleh Yamaura (2011) dengan menggunakan metode estimasi 3SLS menganalisa dua model perdagangan kesetimbangan parsial dua negara untuk menguji hipotesis bahwa market power menggeser penjualan Non-GM Soybean. Amerika Serikat sebagai eksportir Non-GM Soybean memiliki market power lebih besar dari impor Non-GM Soybean Jepang.

Pendekatan estimasi dari kurva residual demand yang dihadapi oleh perusahaan atau sekelompok perusahaan atau dengan kata lain kurva permintaan yang diperoleh karena reaksi dari pesaing ikut dipertimbangkan. Pendekatan ini dikembangkan oleh Baker dan Bresnahan (1988) untuk satu perusahaan sementara Goldberg dan Knetter (1999) menggunakan pendekatan ini pada pasar internasional sehingga menggunakan data tingkat negara. Berbagai macam produk dan pasar baik domestik maupun internasional menggunakan pendekatan ini. Beberapa contoh penelitian pada tingkat negara dalam wilayah produk pertanian dan makanan adalah Carter et al (1999), Tasdogan et al (2005) dan Fahlsbuch (2014).

Carter et al (1999) melakukan analisis dengan pendekatan residual demand elasticity sesuai dengan model yang dikembangkan Goldberg dan Knetter (1999) untuk mengukur derajat competitiveness pasar gandum dimana Amerika Serikat, Australia dan Canada sebagai eksportir utama di negara tujuan Jepang. Dengan menggunakan metode estimasi 2SLS, disimpulkan Amerika Serikat mempunyai kemungkinan sebagai price leader dalam pasar impor gandum Jepang. Yang (2001) menggunakan pendekatan residual demand untuk memeriksa market power dalam industri alumunium Amerika Serikat. Studi dilakukan dengan dua tahap yang pertama menganalisa inverse residual demand elasticity yang dihadapi industri untuk mengukur market power dan kedua mengukur efek potensial dari inter-industry coordination. Estimasi empiris menggunakan model aplikasi dari Baker dan Bresnahan (1988) dan 
dianalisis dengan 3SLS. Industri alumunium primer memiliki market power karena persyaratan modal yang tinggi menjadi hambatan memasuki pasar. Sedangkan pada industri alumunium sekunder menunjukkan struktur pasar kompetitif. Estimasi dari permintaan residual parsial memperlihatkan aksi kolusif yang diambil antara industri alumunium primer dan sekunder.

\section{METODE PENELITIAN}

Data sekunder yang digunakan dalam penelitian ini diambil dari berbagai sumber. Data time series tahunan untuk setiap variabel dikumpulkan dari tahun 1970 - 2013. Data volume ekspor dan nilai impor biji kakao Amerika Serikat diperoleh dari U.S. Census Bureau Trade Data. Harga produksi biji kakao diperoleh dari FAOSTAT website, ICCO dan UNCTAD Report. Nilai tukar mata uang riil rata-rata tahunan diperoleh dari USDA website. Data GDP riil dan Indeks Harga Konsumen diperoleh dan diolah dari website WDI, rata-rata tahunan.

\section{ANALISIS DESKRIPTIF}

Analisis deskriptif adalah bentuk analisis sederhana yang mendeskripsikan dan mempermudah penafsiran dengan pemaparan dalam bentuk tabel, grafik, dan diagram (Dedy 2010). Metode deskriptif digunakan untuk melihat karakteristik pasar tujuan ekspor Amerika Serikat dan persaingan harga antara negara eksportir biji kakao sehingga mendapatkan gambaran kondisi pasar yang dihadapi Indonesia.

\section{MODEL EMPIRIS}

Tahap pertama dari penelitian ini adalah estimasi elastisitas permintaan residual untuk setiap negara eksportir. Model Goldberg dan Knetter (1999) adalah persamaan yang menuliskan variabel-variabel yang disertakan dalam estimasi permintaan residual, seperti volume yang diekspor oleh grup eksportir $\left(Q_{e x}\right)$, penggeser permintaan untuk pasar tujuan ekspor (Z), dan penggeser biaya untuk negara kompetitor $\left(\mathrm{W}^{\mathrm{N}}\right)$. Persamaan tersebut diestimasi dalam bentuk log, koefisien diinterpretasi langsung sebagai elastisitas sehingga persamaan estimasi mengambil bentuk sebagai berikut:

$$
\begin{aligned}
\ln P_{m t}^{e x}= & \lambda_{m}+\eta_{m} \ln Q_{m t}^{e x}+\alpha_{\mathrm{m}}^{\prime} \ln \mathrm{Z}_{\mathrm{mt}}+ \\
& \beta^{\prime} \ln \mathrm{W}_{\mathrm{mt}}^{\mathrm{N}}+\varepsilon_{\mathrm{mt}}
\end{aligned}
$$

ln $\mathrm{P}^{\mathrm{ex}}$ adalah log harga ekspor dari suatu komoditi, dan $\varepsilon_{\mathrm{mt}}$ adalah error term. Di samping parameter di atas subscript $\mathrm{m}$ menunjukkan pasar tujuan ekspor spesifik dari perdagangan bilateral. Vektor $Z_{m t}$ merupakan penggeser permintaan untuk negara $\mathrm{m}, \mathrm{W}_{\mathrm{mt}}^{\mathrm{cn}}$ terdiri dari penggeser biaya untuk $\mathrm{n}$ kompetitor dari grup eksportir yang menghadapi pasar tujuan ekspor tertentu (atau dalam hal ini vektor $\alpha^{\prime}$ and $\beta^{\prime}$ dari parameter). Spesifikasi di atas mengindikasikan bahwa persamaan terpisah harus menjelaskan untuk tiap produk dan tujuan ekspor; harga yang dikenakan oleh grup ekspor $\mathrm{P}_{\mathrm{mt}}^{\mathrm{ex}} \mathrm{t}$ dan penggeser demand diekspresikan dalam unit mata uang tujuan ekspor. Parameter yang menarik adalah $\eta_{\mathrm{m}}$, dari spesifikasi logaritma dapat langsung diinterpretasi sebagai elastisitas permintaan residual. Untuk nilai estimasi nol menunjukkan persaingan sempurna. Dalam hal ini, kelompok eksportir menghadapi kurva elastis sempurna; harga ekspor tidak tergantung kepada jumlah yang diekspor, namun sangat ditentukan dengan biaya dari kompetitor lainnya. Semakin besar nilai $\eta$ absolut, semakin besar deviasi dari penetapan harga biaya marjinal dan semakin kuat export power dari kelompok ekspor.

Penggeser permintaan $Z_{\mathrm{mt}}$ terdiri dari bermacam kombinasi time trend, real income dan tingkat harga dari setiap pasar tujuan ekspor. Penggeser-penggeser biaya ini dapat dipecah menjadi dua bagian; satu bagian ditunjukkan dalam mata uang pesaing bukan spesifik tujuan dan satu bagian yang memvariasi sesuai tujuan ekspor, yaitu exchange rate dari negara pesaing terhadap mata uang negara tujuan ekspor. 
Spesifikasi model empiris dari Goldberg dan Knetter yang dimodifikasi oleh Tasdogan dibuat untuk satu negara eksportir dengan lima negara pesaing eksportir di pasar Amerika Serikat. Dummy yang menyatakan adanya kebijakan bea keluar terhadap biji kakao tanpa diolah atau tidak, dan variabel interaksi antara tahun dan variabel eksogen (harga produsen, exchange rate dan GDP riil) ditambahkan untuk mengetahui dampak dari bea keluar yang dikenakan pada biji kakao Indonesia terhadap harga ekspor biji kakao dari negara pesaing.

$$
\begin{aligned}
\ln P_{m t}^{e x}= & \lambda_{m}+\eta^{\mathrm{ex}} \ln Q_{m t}^{e x}+\beta_{1 m} \ln \mathrm{RGDP}_{\mathrm{mt}} \\
& +\beta_{2 m} \ln E X C_{m t}^{c 1}+\beta_{3 m} \ln P P_{m t}^{c 1} \\
& +\beta_{4 m} \ln \mathrm{EXC}_{\mathrm{mt}}^{\mathrm{c2}}+\beta_{5 m} \ln P P_{m t}^{c 2} \\
& +\beta_{6 m} \ln \mathrm{EXC}_{\mathrm{mt}}^{\mathrm{c3}}+\beta_{7 m} \ln \mathrm{PP}_{\mathrm{mt}}^{\mathrm{c3}} \\
& +\beta_{8 m} \ln \mathrm{EXC}_{\mathrm{mt}}^{\mathrm{c4}}+\beta_{9 m} \ln P P_{m t}^{c 4} \\
& +\beta_{10 m} \ln \mathrm{EXC}_{\mathrm{mt}}^{\mathrm{c5}}+\beta_{11 m} \ln \mathrm{PP}_{\mathrm{mt}}^{\mathrm{c5}} \\
& +\beta_{12} D_{t}+\beta_{13} \ln Q D_{t} \\
& +\sum_{i=14}^{18} \beta_{i} \ln E X C_{c n} D_{t} \\
& +\sum_{i=19}^{23} \beta_{i} \ln P P_{c n} D_{t} \\
& +\beta_{20} \ln R G D P D_{t}+\varepsilon_{m t}
\end{aligned}
$$

dimana:

$P_{m t}^{e x} \quad=$ harga ekspor biji kakao negara eksportir (USD/ton) yang diekspor ke negara tujuan pada tahun ke-t

$\lambda_{m} \quad=$ intercept

$\eta^{\mathrm{ex}} \quad=\ln p_{m t}^{e x}=\lambda_{m}+\eta_{m} \ln Q_{m t}^{e x}+\alpha_{m}^{\prime} \ln Z_{m t}+\beta_{m}^{\prime} \ln W_{m t}^{N}+\epsilon_{m t}$

Elastisitas permintaan residual dari eksportir. Nilai $\eta^{\text {ex }}$ yang mendekati nol menunjukkan persaingan sempurna (semakin elastis). Market power ditunjukkan dengan nilai $\eta^{\text {ex }}$ semakin besar nilai $\eta^{\mathrm{ex}}$ absolut maka market power dari negara eksportir semakin besar.

$Q_{m t}^{e x}=$ volume ekspor biji kakao negara eksportir (ton) ke negara tujuan pada tahun ke-t

$\mathrm{RGDP}_{\mathrm{mt}}=\mathrm{GDP}$ riil dari negara importir/negara tujuan ekspor (USD) pada tahun ke-t

$\mathrm{EXC}_{\mathrm{mt}}^{\mathrm{c} 1}=$ Nilai tukar riil dari negara pesaing $\mathrm{i}$ (USD) pada tahun ket di negara importir.

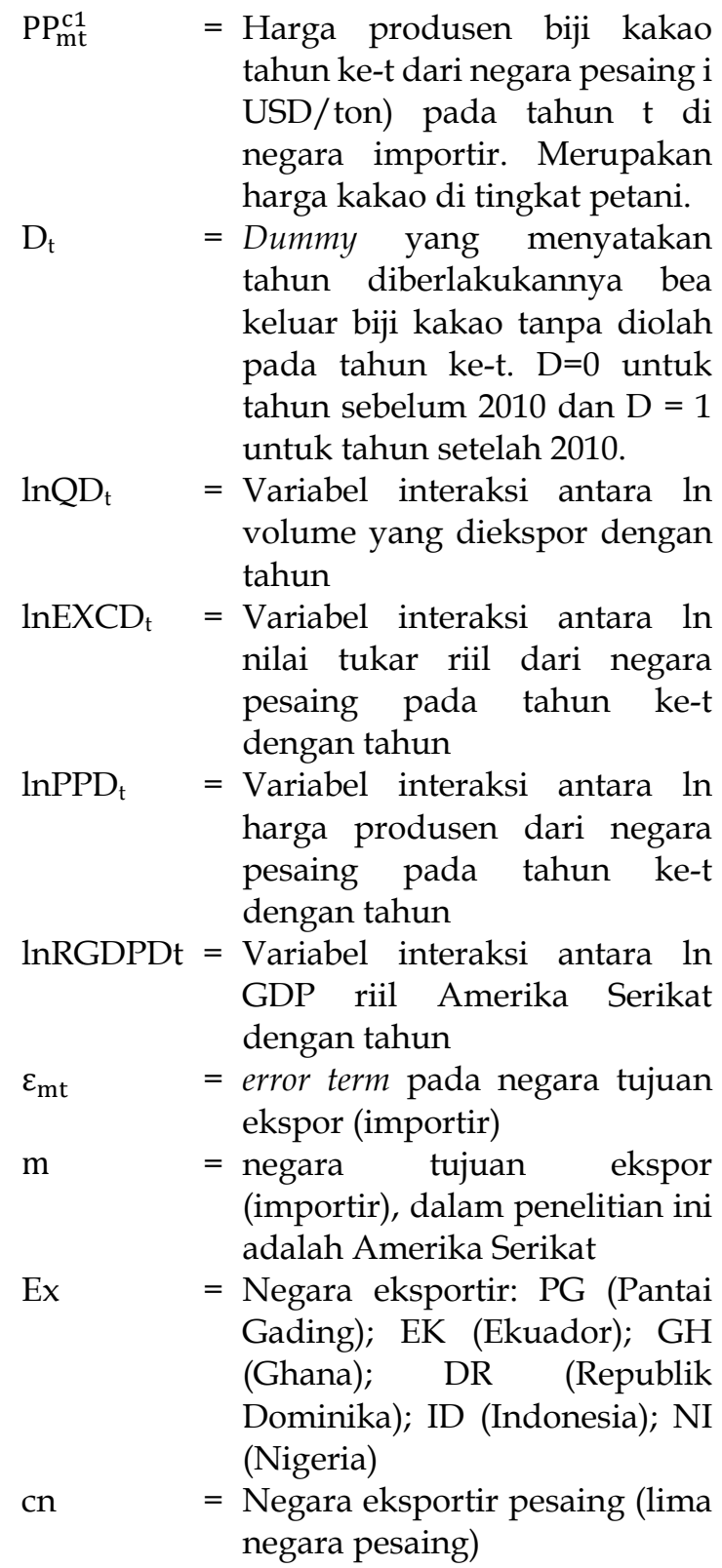

\section{UJI STASIONERITAS DAN UJI KOINTEGRASI}

Variabel-variabel diuji stasionaritasnya agar hasil regresi tidak menghasilkan spurious correlation dengan ekonometrika time series Augmented Dicky Fuller (ADF). Dua variabel yang tidak stasioner sebelum dideferensi namun stasioner pada first difference, besar kemungkinan akan terjadi kointegrasi, artinya ada hubungan jangka panjang di antara keduanya. Uji Johannsens cointegrating test digunakan untuk menguji kointegrasi variabel harga ekspor dan volume ekspor. 


\section{UJI ENDOGENEITY (HAUSMAN TEST)}

Variabel endogen di sisi kanan persamaan akan menghasilkan estimasi bias dengan OLS serta berpotensi memiliki hubungan simultan antara harga dan volume maka dilakukan. Untuk menguji endogeneity digunakan uji spesifikasi Durbin-Wu-Hausman. Ide dari uji Hausman ini untuk melihat jika estimasi dari OLS dan IV adalah berbeda. Jika tidak terdapat endogeneity maka OLS dan IV konsisten tapi IV tidak efisien.

\section{UJI TWO STAGE LEAST SQUARE (2SLS)}

Setelah diperoleh hasil endogeneity, dilakukan estimasi dengan 2SLS bila menunjukkan adanya simultaneity. Langkah pertama dari uji ini adalah memilih Instrumental Variable (IV). Sebuah persamaan reduced form di bawah ini diestimasi untuk mendapatkan IV persamaan pasar tujuan:

$$
\ln Q^{\mathrm{ex}}=\beta_{\mathrm{m}}^{\prime} \ln \mathrm{IV}_{\mathrm{m}}+\xi_{\mathrm{m}}
$$

IV menunjukkan instrument variable yaitu suatu vektor eksogen atau predicted variables yang berhubungan kuat dengan $Q^{\text {ex }}$ dan tidak berkorelasi dengan gangguan. $\beta_{\mathrm{m}}^{\prime}$ mewakili koefisien vektor yang diestimasi dan $\xi_{\mathrm{m}}$ adalah error term. Setelah estimasi dengan 2SLS, uji Durbin-Wu-Hausman dilakukan untuk menguji keselurah sistem.

\section{PERHITUNGAN TERMS OF TRADE}

Tahap kedua dari penelitian ini adalah menghitung terms of trade (TOT). Salah satu perhitungan terms of trade yang meliputi suatu sektor adalah Terms of Trade yang menghitung rasio dari harga internasional dengan harga konsumer barang dan Jasa (Ratio of the Internasional Crops to the Prices of Consumer Goods and Services) menurut Khan dan Ahmed (2004). Terms of trade ini menggunakan dua indeks yaitu indeks harga internasional pertanian yang petani dapat dari pasar internasional (dibawah skenario perdagangan bebas) dan indeks harga konsumen. Ada dua pengukuran TOT yaitu Domestic TOT dan Internasional Price TOT. Rasio dari indeks harga domestik yang diterima petani (Indeks harga produsen) dan indeks harga konsumen digunakan untuk menghitung Domestic TOT. Sementara itu international price TOT menggunakan rasio antara indeks harga produsen internasional (dalam kerangka perdagangan internasional petani diasumsikan langsung menjual biji kakao tanpa perantara) dengan indeks harga konsumen. Perhitungan kedua TOT sebagai berikut:

$$
\text { TOT }=\frac{P I}{I H K} \times 100
$$

dimana:

PI = Indeks harga produsen biji kakao yang diekspor Indonesia (tahun 2000 sebagai tahun dasar)

IHK = indeks harga konsumen Indonesia (tahun 2000 sebagai tahun dasar)

Sebelumnya PI harus diboboti untuk setiap komoditi:

$$
P I=\sum_{j=1}^{20} W_{o j} \times\left(P_{i j} / P_{o j}\right) \times 100
$$

dimana:

PI = indeks harga untuk suatu grup,

$\mathrm{j}=$ komoditi

$\mathrm{i}=$ tahun,

Woj = bobot komoditi ' $j$ ' dalam tahun dasar o',

$\mathrm{Pij}=$ harga komoditi ' $\mathrm{j}$ ' tahun sekarang dan

Poj = harga komoditi ' $j$ ' tahun dasar.

$$
\mathrm{W}=\mathrm{q}_{\mathrm{oj}} \times \mathrm{P}_{\mathrm{oj}} / \sum_{\mathrm{j}=1}^{20} \mathrm{q}_{\mathrm{oj}} \times \mathrm{P}_{\mathrm{oj}}
$$

dimana:

$W=$ bobot komoditi ' $j$ ',

qoj $=$ volume komoditi ' $j$ ' pada tahun dasar.

\section{HASIL DAN PEMBAHASAN}

\section{GAMBARAN UMUM NEGARA-NEGARA EKSPORTIR BIJI KAKAO DI PASAR AMERIKA SERIKAT}

Harga biji kakao di dunia sangat berfluktuasi disebabkan oleh banyak faktor seperti lamanya transportasi kakao menuju pelabuhan, terbatasnya waktu penjualan di bursa komoditi, kondisi cuaca ekstrim seperti 
musim hujan atau kering, dan kondisi politik yang tidak stabil di negara penghasil kakao. Pembentukan harga kakao juga merupakan masalah yang kompleks. Faktor utama yang mempengaruhi pembentukan harga kakao adalah pasokan kakao. Ada dua masalah struktural yang dihadapi oleh penghasil kakao. Pertama adalah harga kakao yang berfluktuasi dalam jangka pendek. Kedua adalah fluktuasi dari harga kakao yang diatur oleh pasar komoditi internasional di London (LIFFE) dan New York (CSCE). Fluktuasi harga dalam jangka pendek berarti petani (dan pemerintah) tidak mampu memprediksi harga yang mereka akan terima (Cocoa Market 2002).

Gambar 2 memperlihatkan pergerakan harga biji kakao dari negara-negara eksportir kakao di Amerika Serikat. Harga kakao dunia sendiri masih berpatokan pada harga kakao Pantai Gading. Harga kakao mencapai puncaknya pada tahun sebelum 1970an karena produksi yang melimpah namun dikuasai oleh perusahaan negara di negara penghasil kakao melalui marketing board (belum diliberalisasi). World Trade Organization (WTO) dan International Monetary Fund (IMF) memberikan bantuan kepada negaranegara Afrika seperti Nigeria, Pantai Gading dan Ghana untuk merekstrukturasi per- dagangan kakao dengan program Structural Adjustment Programs (SAP). Marketing board dibubarkan, persaingan antar eksportir dibuka seluas-luasnya. Namun harga kakao di tahun 1985 masih rendah di bawah tahuntahun sebelumnya. Liberalisasi perdagangan kakao membawa dampak positif dan negatif bagi negara penghasil kakao. Petani kakao mendapatkan pangsa dari harga ekspor yang lebih besar, namun meskipun besar harga kakao dunia menjadi turun karena pasokan bertambah dan harga ekspor diharmonisasi. Petani menghadapi fluktuasi harga kakao dunia (Gilbert dan Varangis 2003).

Biji kakao dihasilkan dari mulai petani kecil, perkebunan skala menengah hingga skala besar. Perbedaan produksi kakao ini menghasilkan perbedaan harga biji kakao yang diterima antara petani, perantara dan eksportir. Penghasil biji kakao di Afrika Barat didominasi oleh petani kecil sedangkan negara penghasil biji kakao lain seperti Brazil lebih cenderung memproduksi kakao dalam skala komersil, Indonesia selain petani kecil juga terdapat perkebunan milik swasta dan pemerintah. Berikut ini adalah gambaran umum negara penghasil biji kakao yang menjadi pemasok biji kakao di pasar Amerika Serikat.

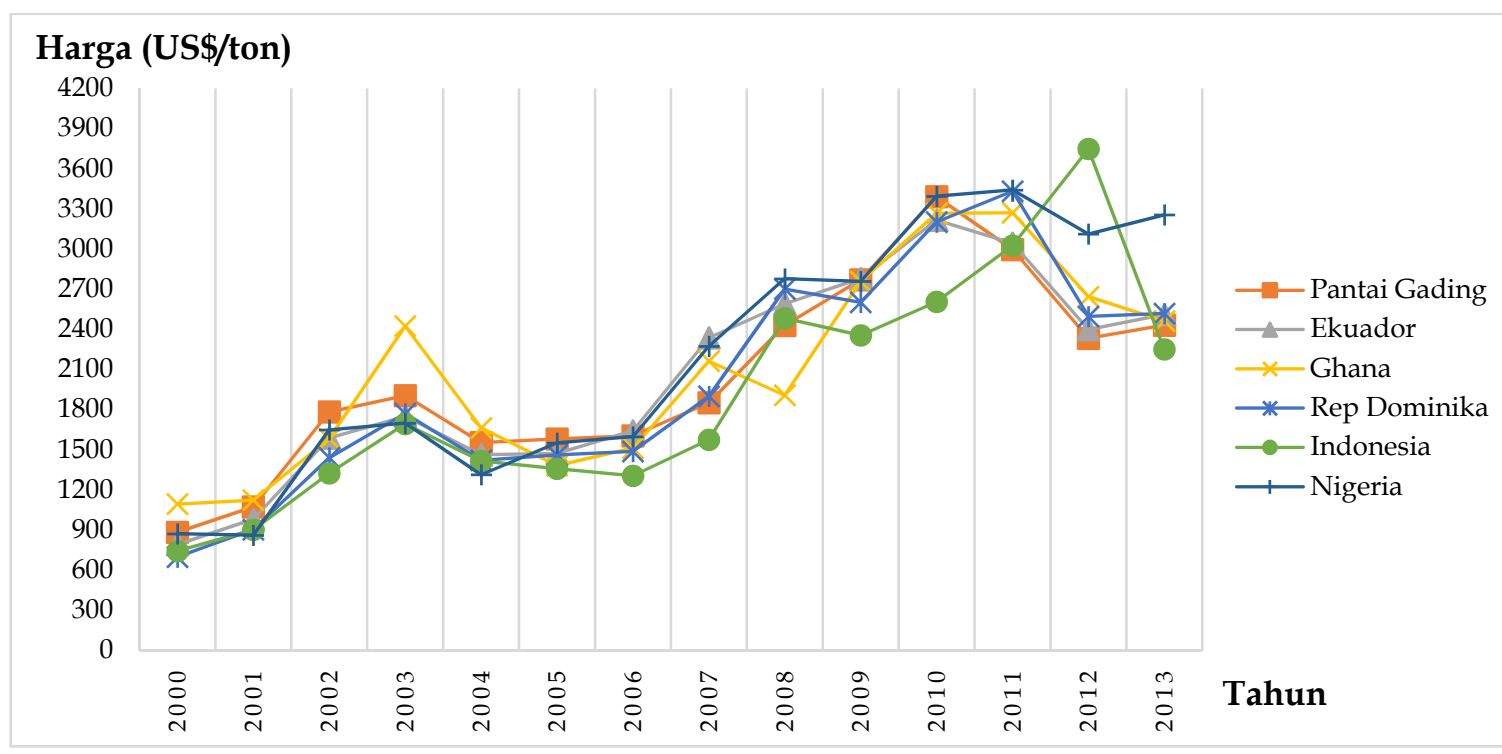

Gambar 2. Pergerakan Harga Biji Kakao dari Negara-Negara Eksportir Terbesar di Pasar Amerika Sumber: GATS 2014 


\section{PANTAI GADING}

Kakao merupakan komoditi unggulan bagi Pantai Gading, di tahun 2008 sektor kakao menyumbang sebesar 25-30 persen dari total ekspor dan memberikan penerimaan negara 17-20 persen. Pantai Gading adalah penghasil kakao utama di dunia. Produksi biji kakao di tahun 2012 sebesar 1.485,9 ribu ton dan ekspor biji kakao ke Amerika Serikat sebesar 231.782 ton. Pasar kakao di Pantai Gading berbentuk piramida terbalik dimana produser dan pengumpul terdesentralisasi namun ekspor dan konsumsi biji kakao sangat terkonsentrasi. Kakao diproduksi oleh petani kecil di Pantai Gading, diestimasi antara 600.000 - 800.000 petani. Perantara membeli kakao langsung dari petani di desa kemudian mengumpulkan kakao di kota besar. Aktivitas memerlukan ijin. Berdasarkan jumlah ijin yang dikeluarkan totalnya 1000 ijin namun hanya 188 orang yang terdaftar sebagai buyer (Kireyev 2010). Dari pusat pengumpulan kakao yang terletak di kota besar, kakao kemudian dibawa ke gudang di daerah pelabuhan Abidjan atau San Pedro. Gudang biasanya milik perusahaan yang terdaftar sebagai eksportir kakao. Jumlahnya tidak melebihi 50-60. Biji kakao dari Pantai Gading mendapatkan harga premium karena biji kakaonya selain mengandung lemak juga memiliki flavour karena telah difermentasi dengan baik.

\section{EKUADOR}

Selama tahun 2012, menurut ICCO (2014) Ekuador menghasilkan biji kakao sebanyak 198 ribu ton. Dari jumlah tersebut yang diekspor ke Amerika Serikat sebesar 53.358 ton. Amerika Serikat adalah negara tujuan utama ekspor biji kakao Ekuador. Dua jenis kakao yang ditanam di Ekuador adalah CCN51 dan National Cocoa. Varietas National Cocoa adalah kakao unggulan asli dari Ekuador yang terkenal sebagai "fine or flavour" cocoa. Varietas National Cocoa menghasilkan panen yang sedikit dan hanya ditanam oleh perkebunan kecil dan menengah.
Sebaliknya CCN51 adalah jenis hibrida dengan hasil banyak dan sebagian besar diproduksi oleh perkebunan skala besar. CCN51 adalah substitusi bagi kakao curah dari Afrika Barat namun belum memiliki pasar ekspor yang signifikan karena mempunyai masalah keasaman yang tinggi. Industri pengolahan kakao dan pembuat cokelat lokal Ekuador menyukai CCN51 karena kandungan cocoa butter nya tinggi dan tidak mempunyai masalah jamur, sebagai hasil dari penanganan masa setelah panen yang bagus oleh perkebunan komersial (Colinson dan Leon 2000).

Sebagian besar eksportir kakao meyakinkan dominasi dari National Cocoa tidak boleh digantikan oleh CCN51. Mereka sangat fokus bahwa Ekuador tidak boleh kehilangan reputasi fine or flavour, namun yang lebih penting mereka khawatir akan kehilangan perbedaan harga positif dari standar tinggi National Cocoa. Profitabilitas eksportir mengandalkan dari perbedaan ini. Sebagai bentuk respon dari masalah ini, eksportir kakao Ekuador membentuk ANACACAO, asosiasi yang mengawal integritas ekspor National Cocoa dan mensertifikasi kualitas. Asosiasi juga menetapkan harga referensi harian yang digunakan untuk menghitung biaya yang eksportir harus bayarkan untuk mendapatkan sertifikasi ekspor. Harga referensi ini berdasarkan harga dari the New York Coffee, Sugar and Cocoa Exchange (CSCE) dikurangi biaya dan keuntungan eksportir. Kakao Ekuador dipasarkan tanpa campur tangan pemerintah. Harga lokal diatur oleh harga internasional dan oleh penawaran dan permintaan lokal. Permintaan dari industri pengolahan kakao Ekuador dan negara tetangga kadang membuat harga lokal berpindah dari harga New York dan London.

\section{GHANA}

Ghana adalah negara penghasil biji kakao terbesar kedua di dunia. Sekitar 43.164 ton biji kakao tersebut diekspor ke Amerika Serikat di tahun 2012. Kakao seperti komoditi lain selalu didiferensiasi dengan country of 
origin dan hal ini berhubungan dengan reputasi berdasarkan kualitas rata-rata. Pada umumnya Ghana menerima harga premium untuk kakaonya di pasaran dunia karena kandungan lemak tinggi di atas rata-rata; tingkat pecahan yang rendah; sehingga menghasilkan cocoa butter yang tinggi daripada biji kakao yang mengandung pecahan yang tinggi dan tingkat cacat biji kakao yang rendah sehingga menghasilkan rasa dan aroma cocoa liquor yang disukai oleh beberapa industri cokelat. Selain itu, reputasi dari Cocoa Marketing Company (divisi pemerintah yang mengelola ekspor) dalam menyakinkan konsistensi dan reliabilitas pengiriman dan dokumen kakao berperan penting dalam membangun reputasi biji kakao berkualitas tinggi (Agrisystem 1997). COCOBOD adalah marketing board yang menjalankan mandat pemerintah Ghana dalam sektor kakao.

Kakao ekspor Ghana sudah difermentasi dan terjaga kualitasnya karena pemerintahnya hanya mengijinkan kakao yang berkualitas jelek diolah didalam negeri. Salah satu alasan pemerintah Ghana menjaga kualitas biji kakao adalah biji kakao diekspor dalam kondisi curah sehinggi biji yang cacat dan bermutu rendah akan mempengaruhi keselurahan biji kakao dalam pengiriman sehingga dapat menurunkan harga. Karakteristik yang menentukan kualitas kakao termasuk kandungan dan kualitas lemak, konsistensi ukuran biji kakao dan kandungan air. Karakter-karakter ini menentukan kualitas cocoa butter dan cocoa liquor yang dihasilkan dari biji kakao, dua bahan yang mengontrol tekstur, aroma, warna dan rasa cokelat. Fermentasi, pengeringan, penyimpanan dan evakuasi biji yang basah merubah kualitas biji kakao secara dramatis, terutama dalam peningkatan rasa dari cocoa liquor. Rasa kakao Afrika barat klasik diperoleh dengan memfermentasikan biji kakao dalam tumpukan daun pisang selama 6 hari dengan sering dibalik secara manual dan dikeringkan dengan sinar matahari. Biji kakao dikeringkan perlahan diatas platform tinggi, sangat penting untuk kualitas dari aroma karena dengan cepat mengurangi tingkat keasaman dari biji kakao. Kualitas juga dipertahankan dengan dengan cepat mengumpulkan biji kakao yang sudah difermentasi dan kering dari para petani dan langsung dikapalkan untuk menghindari dari meningkatnya kelembaban, jamur dan asam lemak bebas yang dapat merusak kualitas biji kakao (Kolavalli, S dan Vigneri, M 2011).

\section{REPUBLIK DOMINIKA}

Kakao di Republik Dominika diproduksi sebagian besar oleh petani kecil dan petani pemilik lahan besar, hanya sedikit yang dihasilkan dari perkebunan komersil. Varietas Trinitario yang tumbuh di Karibian menghasilkan cokelat dengan aroma dan rasa yang khas. Varietas ini hanya diproduksi sedikit di dunia, dimana varietas biji kakao Forastero lebih mendominasi. Meskipun kedua jenis kakao ini dihasilkan di Republik Dominika, namun varietas Trinitario lebih banyak dihasilkan. Menurut ICCO di tahun 2012 produksi biji kakao Republik Dominika mencapai 72,2 ribu ton, dari jumlah tersebut hampir separuhnya diekspor ke Amerika Serikat.

Di awal tahun 1980an Republik Dominika menghasilkan biji kakao yang kualitasnya rendah karena penanganan hasil panen yang tidak baik. Kemudian perusahaan kakao Conacado didukung organisasi pembangunan internasional membantu investasi dalam fasilitas pengeringan dan fermentasi sehingga negara tersebut mampu memproduksi kakao yang berkualitas ke pasar internasional. Meskipun begitu kakao unfermented tradisional Sanchez tetap diproduksi dengan volume besar. Secara total, ekspor kakao menghasilkan revenue US\$160 juta di tahun 2009. Sanchez adalah kakao yang tidak difermentasi dan tidak cukup kering, kondisi alam Dominika yang bercurah hujan tinggi membuat petani kesulitan mengeringkan dengan hanya sinar matahari. Kakao yang dikeringkan dengan baik dan difermentasi sekarang dikenal dengan nama Hispaniola (harganya lebih tinggi) menjadi titik kebangkitan sektor kakao di tahun 1990an. 
Republik Dominika juga berhasil dalam memproduksi biji kakao organik dan menjadi penghasil kakao organik terbesar di dunia. Berdasarkan data Ministry of Agriculture Dominica Republic di tahun 2009-2010, produksi kakao Sanchez sebesar 30.102 ton (senilai 92.043.979 US\$) dan Hispaniola sejumlah 7.387 ton (senilai 24.250.316 US\$), sedangkan untuk kakao Sanchez organik 1.889 ton (senilai 5.501.241 US\$) dan Hispaniola organik sebesar 9.714 ton (33.056.201 US\$) (Berlan dan Bergés 2013)

\section{INDONESIA}

Indonesia menghasilkan biji kakao sebanyak 440 ribu ton pada tahun 2012 menurut ICCO. Petani rakyat menyumbang 87\% kepada produksi nasional, perkebunan negara $8 \%$ dan hanya 5\% dari perkebunan swasta. Provinsi Sulawesi Selatan menjadi pusat penghasil kakao terbesar di Indonesia. Di daerah ini menghasilkan biji kakao yang berlimpah saat panen namun tidak mempunyai flavor. Biji kakao Indonesia mempunyai karakteristik mengandung lemak tinggi daripada rasa cokelat. Varietas ini berasal dari Malaysia (Yasa 2008). Biji kakao Indonesia diserap oleh pasar internasional Malaysia dan Amerika Serikat karena kedua negara tersebut masih menerima biji kakao yang belum difermentasi. Sementara pasar Eropa menghendaki biji kakao yang sudah difermentasi karena berkepentingan dengan aroma dan cita rasa. Sebenarnya Indonesia juga memproduksi biji kakao yang difermentasi seperti yang dipersyaratkan oleh pasar Eropa. Sumatera bagian barat yang terpusat di Kapahiyang dan Padang Sidempuan menjadi wilayah penghasil kakao fermentasi. Sentra kakao di Sulawesi sudah tidak dapat diharapkan untuk menghasilkan biji kakao fermentasi karena petani kakao di sana sudah terbiasa memproduksi biji kakao asalan, dengan alasan selisih harga antara biji kakao yang tidak difermentasi dengan yang difermentasi tidak signifikan. ${ }^{1}$

Petani kakao Indonesia mendapatkan harga $85 \%$ dari harga FOB namun karena adanya praktik ijon dari agen perantara mendorong petani hanya mengejar volume bukan kualitas biji kakao. Menurut satu narasumber, marjin antara harga FOB dan harga petani di Indonesia bisa dipecah menjadi biaya pemasaran dan logistik (10\%), marjin kolektor/trader (3-4\%), dan marjin eksportir (2\%). Marjin yang sedikit bagi kolektor dan trader di dalam value chain mendorong mereka melakukan perdagangan yang cepat dan transaksi tinggi. Trader hanya mengejar volume biji kakao, sehingga biji kakao yang tidak bagus mutunya dicampur dengan biji yang bagus. Hal ini menyebabkan harga biji kakao Indonesia mendapat diskon harga di pasar internasional (Panlibuton dan Meyer 2004).

\section{NIGERIA}

Nigeria adalah negara eksportir biji kakao terbesar keempat di dunia, setelah Pantai Gading, Indonesia dan Ghana. Ekspor kakao adalah ekspor komoditi pertanian utama Nigeria bahkan jika ekspornya berkontribusi 0,3\% dari GDP pertanian (IFPRI 2010). Kakao Alomnado adalah varietas yang ditanam di Nigeria, merupakan varietas kakao dengan kualitas tertinggi sering dikaitkan dengan harga premium di pasar internasional. Nigeria mengekspor biji kakaonya terbesar ke Uni Eropa, dengan pangsa terbesar ke Belanda.

Produksi biji kakao dilakukan oleh petani kecil sekitar 30 ribu petani . Area yang dipanen bervariasi di setiap negara bagian Nigeria namun rata-rata berukuran 2,5 ha. Secara total, setiap petani rata-rata menghasilkan kurang dari 5 karung per musim (300 kg per hektar kakao). Biji kakao dipanen antara bulan Desember dan Juni. Sektor ini dikelola tanpa menggunakan mesin dan

${ }^{1}$ Sumber : http://rpn.co.id/site/homes/artikel/103/MESTINYA-GERNAS-KAKAO-DILANJUTKAN, diakses tanggal 10 November 2014 
dipanen menggunakan tangan. Biji kakao difermentasi selama seminggu dan kemudian dikeringkan selama 3 minggu. Setelah itu dimasukkan ke dalam karung dan diekspor. Dalam rantai ekspor, biasanya Local Area Agents (LAAs) atau Local Buying Agents (LBAs) membeli biji kakao dari petani kemudian pembeli melakukan grading, melibatkan inspeksi kualitas oleh agen grading. LBA adalah perusahaan, individu atau lembaga kerjasama. Biji kakao yang sudah digrading kemudian dijual ke eksportir atau industri pengolahan lokal (Nzeka 2014)

\section{DAMPAK BEA KELUAR KAKAO INDONESIA TERHADAP COUNTRY MARKET POWER DI PASAR BIJI KAKAO AMERIKA SERIKAT}

Analisis pendahuluan yang dilakukan untuk menganalisis data time series dalam penelitian ini adalah uji stasioneritas dan uji kointegrasi. Analisis stasioneritas dari variabel-variabel dalam penelitian ini digunakan untuk memastikan hasil analisis regresi linear berganda tidak menghasilkan spurious correlation maka semua variabel yang dilibatkan dalam model diuji kestasionerannya. Hasil Augmented Dickey Fuller (ADF) menunjukkan variabel-variabel dalam persamaan belum stasioner pada tingkat level namun setelah didiferensiasi pada orde pertama sudah satsioner. Dua variabel yang belum stasioner dapat memiliki akan terjadi kointegrasi. Sehingga hasil analisis market power ini terdapat hubungan jangka panjang antar variabelnya.

Uji endogeneity dilakukan untuk menunjukkan adanya hubungan simultan antara variabel harga dan volume ekspor. Estimasi volume ekspor mengandung potensi bersifat endogenous karena adanya hubungan simultan dengan harga ekspor. Setelah dipilih instrumen yang tepat untuk volume ekspor dilakukan uji spesifikasi Hausman apakah variabel bersifat eksogen atau endogen. $\mathrm{H} 0$ adalah variabel eksogen, tolak H0 berarti estimasi dengan OLS tidak konsisten sehingga estimasi menggunakan 2SLS lebih tepat. Hasil uji endogeneity menunjukkan model persamaan bagi semua negara lebih baik diestimasi dengan 2SLS.

Tabel 3 merangkum semua hasil estimasi persamaan permintaan inverse dari setiap negara eksportir biji kakao dalam penelitian ini. Semua persamaan dalam bentuk loglinear diestimasi untuk setiap negara menggunakan Two Stage Least Square (2SLS) dengan menggunakan asumsi imperfect competition. Koefisien dari volume ekspor menunjukkan

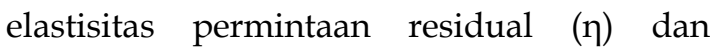
diintrepertasi langsung sebagai market power. Variabel-variabel bebas yang mempunyai masalah kolinearitas dihilangkan dalam model persamaan untuk setiap negara pada saat diestimasi dengan metode 2SLS.

Hasil estimasi menunjukkan bahwa semua negara memiliki market power ditunjukkan dengan koefisien dari log volume ekspor yang bertanda negatif dan signifikan pada taraf nyata $a=$ lima persen. Tanda negatif menunjukkan dalam struktur pasar persaingan tidak sempurna berlaku pembatasan volume ekspor akan meningkatkan harga ekspor. Koefisien ini adalah elastisitas permintaan residual yang dilihat secara langsung sebagai derajat market power. Tabel 3 memperlihatkan hasil estimasi persamaan permintaan inverse dari negara-negara eksportir biji kakao di pasar Amerika yaitu Indonesia, Pantai Gading, Ekuador, Ghana, Republik Dominika dan Nigeria. Pengenaan pajak ekspor terhadap biji kakao Indonesia memberikan dampak terhadap market power Indonesia, Pantai Gading dan Ghana. Sedangkan market power dari negara Ekuador, Republik Dominika dan Nigeria tidak terpengaruh oleh pembatasan volume ekspor biji kakao oleh pemerintah Indonesia. Sebelum adanya pengenaan pajak ekspor, Indonesia memiliki market power 0,217 namun setelah itu market power Indonesia semakin menurun menjadi 0,046. Hasil ini menunjukkan Indonesia tidak memiliki daya saing di pasar Amerika Serikat sebagai eksportir biji kakao. Sedangkan untuk Pantai Gading, market power sebelum ekspor Indonesia dikenakan pajak sebesar 1,319 kemudian 
setelah adanya pajak market power Pantai Gading bertambah menjadi 2,67. Ghana juga mengalami peningkatan market power, sebelum adanya pajak ekspor market powernya 0,427 .

Setelah ekspor biji kakao Indonesia dikenai pajak, maka market powernya menjadi 2,067. Kedua negara penghasil biji kakao ini mendapat keuntungan dari pembatasan volume ekspor biji kakao Indonesia.

Variabel-variabel eksogen dari persamaan permintaan inverse seperti harga produksi (pp) dan nilai tukar riil terbukti tidak mendapat pengaruh dari pengenaan bea keluar sehingga dalam estimasi dengan 2SLS, variabel-variabel dummy interaksinya dihilangkan. Variabel penggeser permintaan GDP riil Amerika Serikat signifikan dan menunjukkan tanda positif kecuali untuk Republik Dominika. Hal ini menunjukkan permintaan biji kakao dari Amerika yang besar.

Faktor-faktor yang mempengaruhi harga biji kakao setiap negara eksportir dalam penelitian ini di pasar Amerika Serikat ternyata berbeda-beda. Harga biji kakao Indonesia hanya dipengaruhi oleh perubahan harga produsen Republik Dominika, nilai tukar Pantai Gading dan Ghana. Pantai Gading sebagai price leader dipengaruhi oleh harga produsen negara tetangganya Ghana, nilai tukar Ekuador dan Indonesia. Harga biji kakao Ghana dipengaruhi oleh harga produsen Ekuador, Republik Dominika, Indonesia, dan Nigeria, nilai tukar Pantai Gading dan Republik Dominika juga mempengaruhi harga biji kakao Ghana. Harga biji kakao Ekuador sangat dipengaruhi oleh harga produsen Pantai Gading, nilai tukar Ghana dan Indonesia. Republik Dominika memiliki market power terbesar ketiga dimana harga biji kakaonya dipengaruhi oleh harga produsen negara Ekuador, Ghana, Indonesia dan Nigeria, serta nilai tukar Ghana. Sedangkan harga biji kakao Nigeria dipengaruhi oleh harga produsen Pantai Gading dan Republik Dominika, nilai tukar dari negara Pantai Gading, Ekuador, Ghana, Republik Dominika dan Indonesia.

Hasil analisis dampak bea keluar kakao tanpa olahan dari Indonesia terhadap market power negara-negara eksportir disajikan dalam Tabel 4. Dominasi Pantai Gading di pasar biji kakao Amerika Serikat terlihat dari meningkatnya market power negara tersebut saat Indonesia membatasi ekspor biji kakao ke Amerika Serikat. Negara tetangga Pantai Gading yaitu Ghana juga mendapatkan keuntungan dari pengenaan bea keluar kakao dari Indonesia. Kedua negara ini menjadi pesaing terbesar Indonesia karena biji kakao yang mereka hasilkan berkualitas premium dan produksi biji kakao per tahun yang besar.

Tabel 3. Faktor-faktor yang Mempengaruhi Harga Biji Kakao Indonesia dan Lima Negara Pesaing Eksportir Biji Kakao di Pasar Amerika

\begin{tabular}{|c|c|c|c|c|c|c|c|c|c|c|c|c|c|c|c|c|c|}
\hline \multicolumn{3}{|c|}{ Indonesia } & \multicolumn{3}{|c|}{ PantaiGading } & \multicolumn{3}{|c|}{ Ghana } & \multicolumn{3}{|c|}{ Ekuador } & \multicolumn{3}{|c|}{ Rep Dominika } & \multicolumn{3}{|c|}{ Nigeria } \\
\hline Inpid & Koefisien & Prob & lnppg & Koefisien & Prob & Inpgh & koefisien & Prob & Inpek & koefisien & Prob & $\operatorname{lnp} d x$ & koefisien & Prob & Inpni & koefisien & Prob \\
\hline Ingid & $-0,217^{\mathrm{mm}}$ & 0,000 & lnapg & $-1,319^{\mathrm{m}}$ & 0,015 & lnggh & $-0,427^{\mathrm{cm}}$ & 0,004 & lngek & $-0,539=$ & 0,001 & $\operatorname{lng} d x$ & $-0,766^{\mathrm{mm}}$ & 0,000 & Ingni & $-0,126^{\mathrm{mm}}$ & 0,004 \\
\hline lnxgdp & $1,593^{\mathrm{m}}$ & 0,001 & lnrgdp & $3,456^{\mathrm{m}}$ & 0,034 & lrrgdp & $2,286^{\mathrm{m}}$ & 0,019 & lrrgdp & $1,525^{\mathrm{om}}$ & 0,002 & lnxgdp & $-0,614$ & 0,143 & lnrgdp & $0,530^{\mathrm{m}}$ & 0,012 \\
\hline lnppdx & $0,403^{\mathrm{mom}}$ & 0,002 & lnppgh & $0,845^{\circ}$ & 0,020 & Inppek & $-0,820^{\mathrm{mm}}$ & 0,013 & lnpppg & $0,320^{*}$ & 0,092 & Inppek & $0,340^{\text {men }}$ & 0,009 & lnpppg & $0,443^{2 m}$ & 0,000 \\
\hline lnexcpg & $.0,302^{*}$ & 0,093 & lnexcek & $-3,012^{\text {twm }}$ & 0,001 & Inppdr & $1,645^{* *}$ & 0,036 & Inexcgh & $0,405^{m+n}$ & 0,008 & lnppgh & $-0,454^{* *}$ & 0,022 & lnppdx & $0,713^{\text {tw }}$ & 0,000 \\
\hline Inexcgh & 0,259 "* & 0,025 & Inexcid & $1,266^{* *}$ & 0,014 & Inppid & $\cdot 0,941^{* *}$ & 0,041 & Inexcid & $-1,288^{m+m}$ & 0,001 & lnppid & $0,606^{* *}$ & 0,017 & lnexcpg & $-0,377^{*}$ & 0,050 \\
\hline IngidD & $0,171^{m+m}$ & 0,005 & & $16,297^{* *}$ & 0,045 & lnppni & $-1,114^{* *}$ & 0,016 & Konst. & $-30,386^{\text {two }}$ & 0,009 & Inppri & $0,724^{-m+1}$ & 0,001 & Inexcek & $.0,780^{\text {the }}$ & 0,001 \\
\hline \multirow[t]{5}{*}{ Konst. } & $-31,243$ & 0,030 & lnapg $D$ & $-1,35^{\text {t }}$ & 0,043 & lnexcps & $-2,722^{\mathrm{ent}}$ & 0,002 & & & & lnexcgh & $0,229^{* *}$ & 0,030 & Inexcgh & $0,421^{m+t}$ & 0,000 \\
\hline & & & Konst. & $.68,618^{*}$ & 0,073 & Inexcdr & $-3,942^{\mathrm{out}}$ & 0,009 & & & & Konst. & $28,422^{2 n+}$ & 0,009 & Inexcdr & $-0,351^{*}$ & 0,076 \\
\hline & & & & & & Indipgh & $-0,278^{*}$ & 0,015 & & & & & & & Inexcid & $-0,357^{*}$ & 0,085 \\
\hline & & & & & & & $17,18^{\operatorname{mot}}$ & 0,004 & & & & & & & & & \\
\hline & & & & & & IngghD & $-1,640^{\text {ont }}$ & 0,005 & & & & & & & & & \\
\hline$R^{2}$ & 0,909 & & $R^{2}$ & 0,669 & & $\mathbb{R}^{2}$ & 0,951 & & $R^{2}$ & 0,627 & & $R^{2}$ & 0,832 & & $\mathbb{R}^{2}$ & 0,866 & \\
\hline F-stat & 14,07 & & F-stat & 20,43 & & F-stat & 16,64 & & F-stat & 2,28 & & F-stat & 2,19 & & F-stat & 265 & \\
\hline Prob & 0,0000 & & Prob & 0,0002 & & Prob & 0,0200 & & Prob & 0,0372 & & Prob & 0,0439 & & Prob & 0,0229 & \\
\hline (F-stat) & & & (E-stat) & & & (F-stat) & & & (F-stat) & & & (F-stat) & & & (F-stat) & & \\
\hline
\end{tabular}

Keterangan:

1) Variabel-variabel tak bebas dalam model di atas adalah lnpid, lnppg, lnpgh, lnpek, lnpdr dan lnpni

2) *** menunjukkan tingkat signifikansi pada taraf $\alpha=1$ persen

3) ${ }^{* *}$ menunjukkan tingkat signifikansi pada taraf $a=5$ persen

4) * menunjukkan tingkat signifikansi pada taraf $\alpha=10$ persen 
Tabel 4. Market Power Negara-negara Eksportir Kakao di Amerika Serikat dengan Pengaruh Bea Keluar Kakao Tanpa Olahan dari Indonesia

\begin{tabular}{|l|c|c|c|}
$\begin{array}{c}\text { Negara eksportir } \\
\text { biji kakao }\end{array}$ & $\begin{array}{c}\text { Market Power tanpa } \\
\text { pengaruh dari pajak } \\
\text { ekspor kakao } \\
\text { Indonesia }\end{array}$ & $\begin{array}{c}\text { Market Power } \\
\text { dengan pengaruh } \\
\text { pajak ekspor } \\
\text { kakao Indonesia }\end{array}$ & $\begin{array}{c}\text { Pangsa ekspor di } \\
\text { Amerika Serikat } \\
\text { (2013) }\end{array}$ \\
\hline Pantai Gading & 1,319 & 2,669 & 59,0 persen \\
\hline Ekuador & 0,539 & 0,539 & 15,2 persen \\
\hline Ghana & 0,427 & 2,067 & 13,6 persen \\
\hline Republik Dominika & 0,766 & 0,766 & 4,9 persen \\
\hline Indonesia & 0,217 & 0,046 & 1,9 persen \\
\hline Nigeria & 0,126 & 0,126 & 1,6 persen
\end{tabular}

Ekuador meskipun mempunyai pangsa ekspor yang besar di Amerika Serikat tidak terpengaruh oleh pembatasan ekspor biji kakao Indonesia karena produksi biji kakao Ekuador hanya empat persen dari total produksi dunia. Kapasitas produksi biji kakao Ekuador tidak bisa ditambah lagi sehingga ekspor biji kakao ke Amerika Serikat juga tidak mampu ditingkatkan.

Pangsa ekspor Republik Dominika dan Nigeria yang kecil membuat kedua negara ini tidak terpengaruh oleh bea keluar kakao Indonesia. Selain itu meskipun Nigeria produksi biji kakaonya cukup besar namun Amerika Serikat bukan merupakan pasar tujuan utama.

Penghasil kakao di negara-negara Afrika Barat seperti pantai Gading dan Ghana mendapatkan harga premium di pasar Internasional karena menghasilkan biji kakao yang mengandung keduanya lemak dan flavor. Kakao Sulawesi yang diperdagangkan di pasar internasional merupakan biji kakao unfermented dan kandungan lemak tinggi. Harga biji kakao Indonesia sendiri didiskon sesuai standar yang ditetapkan harga terminal NY karena dicampur antara biji kakao yang sudah difermentasi dengan yang belum difermentasi.

\section{DAMPAK BEA KELUAR KAKAO TANPA OLAHAN TERHADAP TERMS OF TRADE}

Bea keluar adalah instrumen kebijakan yang membatasi volume ekspor secara tidak langsung, merupakan kebijakan yang susah dimengerti daripada kebijakan tarif impor.
Analisa ekonomi menyediakan beberapa justifikasi rasional untuk penggunaan instrumen ini, salah satunya adalah terms of trade. Justifikasi terms of trade adalah justifikasi yang paling penting. Suatu negara dengan pangsa ekspor besar di pasar internasional kemudian membatasi eskpornya dapat membuat harga dunia komoditi yang dibatasi tersebut meningkat. (Bouët dan Debucquet 2010).

Berdasarkan hasil pengukuran market power, Indonesia tidak memiliki market power lagi dalam mengekspor biji kakao di pasar Amerika Serikat, sehingga dapat diperkirakan dampak dari pengenaan bea keluar membuat terms of trade mengalami penurunan. Perhitungan terms of trade dalam penelitian ini merefleksikan perubahan dalam profitabilitas dan standar hidup petani hanya berdasarkan perubahan harga. Terms of Trade yang pertama adalah rasio dari indeks harga domestik yang diterima petani dan indeks harga konsumen dengan tahun dasar 2000 (Gambar 3). Perhitungan terms of trade ini merefleksikan perubahan dalam profitabilitas dan standar hidup petani hanya berdasarkan perubahan harga. Domestic terms of trade dari ekspor biji kakao ini menunjukkan bahwa perubahan harga dengan asumsi volume tetap menyebabkan adanya perbedaan gap dengan indeks harga konsumen. Antara tahun 2005-2010, gap tersebut semakin menurun. Harga produsen yang diterima oleh produsen (dalam hal ini petani) semakin besar. Pada tahun 2010-2012 terjadi penurunan harga produsen namun setelah itu terjadi peningkatan. Dampak dari kebijakan bea keluar membutuhkan waktu penyesuaian 
bagi petani sampai pada satu titik dimana petani dapat memiliki posisi tawar untuk memutuskan menjual ke industri lokal atau eksporter (Rifin 2012).

Asosiasi Kakao Indonesia menilai kebijakan bea keluar kakao memberatkan petani karena harga ditingkat petani akan didiskon. Selain itu bea keluar akan dibebankan kepada petani. Kakao Indonesia sebetulnya mendapat harga premium di pasar internasional namun harga premium kakao Indonesia itu tidak sepenuhnya dinikmati petani karena harus dipotong diskon, yang antara lain terdiri atas instrumen biaya transportasi, keuntungan pengimpor, asuransi, kualitas biji dan bea keluar, yang mencapai US\$200 per ton. Pernyataan ini dibantah oleh Wamen Keuangan Mahendra Siregar karena harga diskon petani malah lebih kecil 5 persen-8 persen dari harga terminal atau lebih rendah dari sebelumnya yang mencapai 12 persen-13 persen $^{2}$

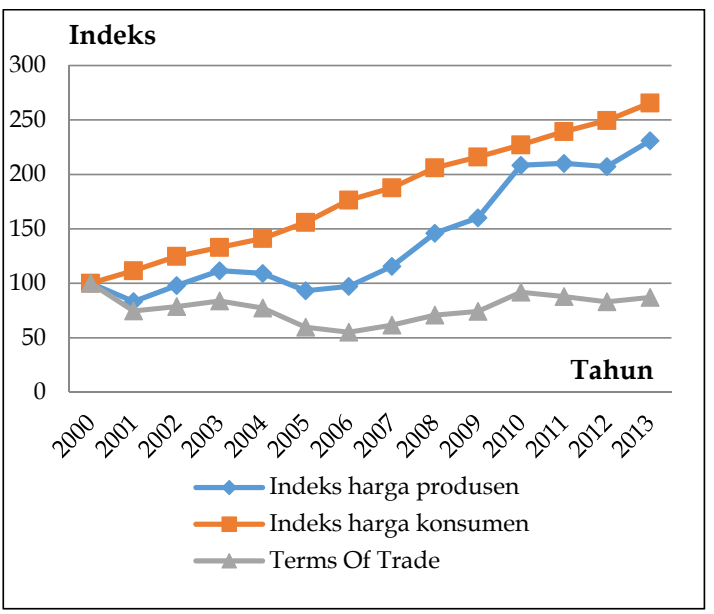

Gambar 3. Terms of Trade dari Ekspor Komoditi Biji Kakao Menggunakan Indeks Harga Domestik

Terms of trade yang kedua adalah terms of trade menggunakan harga internasional komoditi untuk satu komoditi yaitu harga ekspor biji kakao Indonesia ke pasar Amerika dalam kerangka perdagangan bebas dengan asumsi petani dapat menjual langsung biji kakao tanpa perantara namun di Indonesia hanya eksportir yang mempunyai hubungan langsung ke pembeli luar negeri (Gambar 4).

Dari perhitungan indeks harga produsen terlihat bahwa eksportir mendapatkan keuntungan yang terendah dari perdagangan bebas pada tahun 2006 dan mencapai puncaknya pada tahun 2011, selanjutnya terms of trade menurun menuju tahun dasar 2000. Kebijakan bea ekspor menurunkan keuntungan eksportir, karena pada kenyataannya industri luar negeri yang menanggung biaya pajak ekspor terbukti dengan masuknya investasi industri pengolahan kakao di Indonesia.

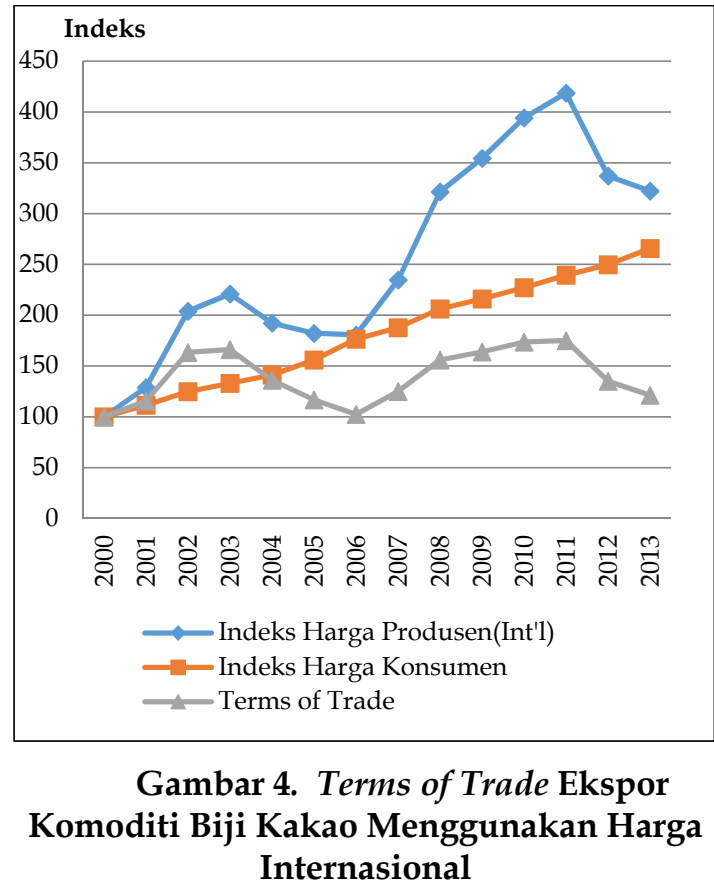

Kebijakan pengenaan bea ekspor telah berhasil mengurangi ekspor biji kakao menjadi 100.000 ton pada tahun 2012/2013. Dampak kebijakan terhadap profitability petani yang dilihat melalui domestic terms of trade menunjukkan bahwa kecenderungan mendekati terms of trade tahun dasar (2000). Dengan berjalannya waktu dapat diprediksi bahwa petani akan mempunyai keuntungan jika menjual biji kakao untuk industri pengolahan lokal. Indonesia mempunyai market di pasar ekspor biji kakao sehingga

\footnotetext{
2 Sumber: http:/ / m.bisnis.com/industri/read/20120510/12/76602/kebijakan-dagang-bea-keluar-kakao-merugikan diakses pada 10 November 2014
} 
pengenaan bea keluar tidak mempengaruhi kesejahteraan nasional.

Sedangkan dari terms of trade menggunakan harga internasional menunjukkan bahwa eksportir kakao mempunyai keuntungan yang lebih besar karena ToTnya di atas tahun dasar (2000). Pengenaan bea ekspor membuat ToT ini menurun cenderung mendekati tahun dasar. Oleh karena itu eksportir yang merasa paling keberatan dengan adanya bea ekspor ini.

Pencabutan kebijakan sebelumnya yakni pajak pertambahan nilai (PPN) 10\% perdagangan komoditas primer hasil perkebunan dalam negeri tidak efektif dalam meningkatkan ketersediaan biji kakao untuk industri domestik. Bahkan, pada 2009 Indonesia mengimpor biji kakao 27.400 ton dan kakao setengah jadi 12.400 ton (Bank Indonesia, 2009). Kemudian pemerintah mengeluarkan kebijakan bea keluar kakao tanpa olahan untuk memperbaiki kebijakan pencabutan PPN 10\%. Namun pengenaan bea keluar kakao tanpa olahan ini telah menurunkan daya saing ekspor biji kakao di pasar Amerika Serikat dan membuat terms of trade pada komoditi ini menurun. Efek bea keluar terhadap distribusi pendapatan sangat dirasakan oleh eksportir. Pemerintah mendapatkan penghasilan dari pajak sementara produsen (petani kakao) kesejahteraannya meningkat. Hal yang perlu dicermati adalah jangka waktu pengenaan bea keluar. Karena semakin lama dilaksanakan maka Indonesia akan kehilangan pangsa pasar dan pendapatan dari mata uang asing.

\section{KESIMPULAN DAN SARAN}

\section{KESIMPULAN}

1. Market power ekspor biji kakao Indonesia di pasar Amerika Serikat sangat kecil. Pengenaan bea ekspor (BK) kakao tanpa olahan menurunkan volume ekspor ke pasar Amerika. Dampak dari bea ekspor terhadap market power Indonesia adalah semakin menurunkan market power ekspor biji kakao. Hasil ini mengindikasikan bahwa Indonesia tidak mempunyai daya saing di pasar kakao Amerika Serikat. Indonesia menghadapi kondisi struktur pasar persaingan sempurna.

2. Pengenaan bea keluar (BK) hanya mempengaruhi market power dari Pantai Gading dan Ghana. Sebagai konsekuensi dari pembatasan volume ekspor kakao dari Indonesia ke Amerika Serikat maka market power kedua negara Afrika Barat ini meningkat. Pantai Gading memiliki market power paling tinggi sesuai dengan market share yang dimilikinya.

3. Hasil perhitungan terms of trade menunjukkan Domestic terms of trade mengalami perbaikan mendekati terms of trade tahun dasar 2000 dan international terms of trade mengalami penurunan sejak diberlakukannya bea keluar kakao tanpa olahan.

\section{SARAN}

Berdasarkan hasil penelitian yang diperoleh, maka dapat disarankan agar kebijakan bea keluar kakao tanpa olahan tetap dilanjutkan agar kebutuhan biji kakao untuk industri pengolahan kakao domestik terpenuhi sehingga mendorong kebijakan hilirisasi sektor kakao.

\section{DAFTAR PUSTAKA}

Agritrade. 2012. Côte d'Ivoire's cocoa sector reforms 2011-2012. Special ReportDecember 2012

Agrisystem. 1997. Study of the Cocoa Sector to Define Interventions on Behalf of Ghana's Smallholder with Particular Reference to the Framework of Mutual Obligations to be Prepared for the Stablex 1992 and 1993 Allocation, Aylesbury.

Baker JB dan Bresnahan TF. 1988. Estimating the Residual Demand Curve Facing a Single Firm. International Journal of Industrial Organization, 6,pp. 283-300. 
Bouët A dan Debucquet DL. 2010. Economics of Export Taxation in a Context of Food Crisis. A Theoretical and CGE Approach Contribution. IFPRI Discussion Paper 00994.

Berlan A dan Bergés A. 2013. Cocoa Production in the Dominican Republic: Sustainability, Challenges and Opportunities. Report on findings commisioned by Green \& Black's.

Carter CA, MacLaren D, dan Yilmaz A. 1999. How Competitive is the World Wheat Market?. Department of Agricultural and Resource Economics, University of California. Working Paper, No. 99-002

Collinson C dan Leon M. 2000. Economic Viability of Ethical Cocoa Trading in Ecuador. Natural Resources and Ethical Trade Programme. Report 2519. Natural Resource Institute. University of Greenwich UK

Dedy M. 2010. Peran Sektor Pertanian dalam Pertumbuhan Ekonomi di Indonesia [Tesis]. Sekolah Pascasarjana-IPB, Bogor. Indonesia

Deodhar SY dan Sheldon IM. 1997. Market Power in the World Market for Soymeal Exports. Western Agricultural Economics Association. Journal of Agricultural and Resource Economics 22(1):78-86.

dan Pandey V. 2006. Degree of Instant Competition: Estimation of Market Power in India's Instant Coffee Market. Paper for Indian Institut of Management Ahmedabad India.

Devarajan S, Delfin G, Maurice S dan Sethaput SN. 1996. The Whys and Why Nots of Export Taxation. Policy Research Working Paper. World Bank

Durevall D. 2005. Demand for Coffee: Prices, Preference and Market Power. Department of Economics School of Economics and Comercial Law University of Goeteborg.
Fahlbusch M. 2014. Price Formation and the Measurement of Market Power on the International Dairy Markets. Dissertation zur Erlangung des Doktorgrades der Fakultät für Agrarwissenschaften der GeorgAugust-Universität Göttingen.

Firdaus M dan Ariyoso. 2010. Keterpaduan Pasar dan Faktor-Faktor yang Mempengaruhi Harga Kakao Indonesia. JKEP Vol. 3 No. 10

Goldberg PK dan Knetter MM. 1999. Measuring the Intensity of Competition in Export Markets. Journal of International Economics 47 (1999) 2760.

Gilbert CL and Varangis P. 2003. Globalization and International Commodity Trade with Specific Reference to the West African Cocoa Producers. NBER Working Paper No. W9668 (May).

International Cocoa Organization (ICCO). 2014. Quarterly Bulletin of Cocoa Statistics, Vol. XL, No. 1, Cocoa year 2013/14 Published: 28-02-2014

Khan AA dan Ahmed QM. 2004. Agricultural Terms of Trade in Pakistan:Issues of Profitability and Standard of Living of the Farmers. The Pakistan Development Review. 43:4 Part II(Winter 2004) pp 515-537

Kireyev A. 2010. Export Tax and Pricing Power: Two Hypotheses on the Cocoa Market in Côte d'Ivoire. WP/10/269. IMF Working Paper.

Kolavalli et. all. 2012. The Partially Liberalized Cocoa Sector in Ghana. Producer Price Determination, Quality Control and Service Provision. IFRI Discussion Paper 01213.

Krugman, P.R., Obstfeld, M., Melitz, M.J. 2012. International Economics. Theory and Policy. Ninth Ed. Pearson. 
Nur Hartono DH. 2010. The Competitiveness of Indonesian Cocoa and Cocoa Products in The US, Singapore, and China. MS [Thesis]. University of Indonesia. Depok

Nzeka UM. 2014. Nigeria Hikes Target on Cocoa Production. Gain Report. Global Agricultural Information Network.

Nwachukwu IN, Onyenweaku CE, Nwaru JC, dan Paveliuc-Olariu C. 2011. Measuring the Degree of Market Power in the Export Demand for Nigerian Cocoa: An Analysis of Dutch Market. Journal of Social and Development Sciences. Vol. 2, No. 3, pp. 94-103, Sep 2011 (ISSN 2221-1152).

Panlibuton H dan Meyer, M. 2004. Value Chain Assesment: Indonesia Cocoa. Microreport\#2. USAID

Piermartini R. 2004. The Role of Export Taxes in the Field of Primary Commodities. World Trade Organization Publication.

Rifin A. 2012. Impact of Export Tax Policy on Cocoa Farmers and Supply Chain. SEADI Working Paper No 1.

Sexton RJ dan Zhang M. 2001. An Assessment of the Impact of Food Industry Market Power on U.S. Consumers. Agribusiness 17, 59-79.

Susanto D. 2006. Measuring The Degree of Market Power in The Export Demand For Soybean Complex. Dissertation. Lousiana University. The Department of Agricultural Economics and Agribusiness.

Tasdogan C, Tsakiridou E, dan Mattas K. 2005. Country Market Power in EU Olive Oil Trade. South-Eastern Europe Journal of Economics 2 (2005) 211-219.

Yamaura K. 2011. Market Power of the Japanese Non-GM Soybean Import Market: The U.S. Exporters vs Japanese Importers. Asian Economic and Social Society. Asian Journal of Agriculture and Rural Development, Vol. 1, No.2, pp 80-89.
Yang SP. 2001. Measuring Market Power in the U.S. Aluminum Industry: A Residual Demand Approach. Review of Industrial Organization; Nov 2001; 19

Yasa IW. 2012. Indonesian Cocoa Beans: Current Situation. www.icco.org 
